\title{
The Importance of Teacher Professionalism in Facing The Industrial Revolution Era 4.0
}

\author{
Indah Novita Sari, Cut Nurul Zara Vonna, Fenti Retnoningrum
}

Universitas Sebelas Maret

inovita193@gmail.com

\section{Article History}

accepted 24/09/2019

approved 01/10/2019

published 01/12/2019

\begin{abstract}
This article aims to exlain the importance of developing teacher professionalism in facing the era of the industrial revolution 4.0. The research method used is the study of literature. Data collection is carried out by conducting a study of books, literature, notes and reports that have to do with the importance of teacher professionalism in facing the industrial revolution era 4.0. so in this article includes general processes such as: systematically identifying the theory, library discovery, and analysis of documents that contain information related to the research topic. The results of this study are in the form of a description related to development that can be dont by teachers to develop teacher professionalism in facing the era of the industrial revolution 4.0 well.
\end{abstract}

Keywords: Teacher Competence, Professionalism, Industrial Revolution

\begin{abstract}
Abstrak
Artikel ini bertujuan untuk menjelaskan pentingnya mengembangkan profesionalisme guru dalam menghadapi era revolusi industri 4.0. Metode penelitian yang digunakan yakni dengan studi kepustakaan. Pengumpulan data dilakukan dengan mengadakan studi penelaahan terhadap buku-buku, literatur-literatur, catatan-catatan dan laporan-laporan yang ada hubungannya dengan pentingnya profesionalisme guru dalam menghadapi era revolusi industri 4.0. sehingga dalam artikel ini meliputi proses umum seperti: mengidentifikasi teori secara sistematis, penemuan pustaka, dan analisis dokumen yang memuat informasi yang berkaitan dengan topik penelitian. Hasil penilitian ini yaitu berupa diskripsi terkait pengembangan yang dapat dilakukan oleh guru untuk mengembangkan profesionalisme guru dalam menghadapi era revolusi industri 4.0 dengan baik.
\end{abstract}

Kata kunci: Kompetensi Guru, Profesionalisme, Revolusi Industri

Social, Humanities, and Education Studies (SHEs): Conference Series https://jurnal.uns.ac.id/shes

p-ISSN 2620-9284

e-ISSN 2620-9292 


\section{PENDAHULUAN}

Era revolusi industri 4.0 yang mana membawa perubahan sistem dari konvensial menjadi berbasis digital yang membawa teknologi menjadi basis dalam kehidupan manusia. Hal ini menjadikan segala hal yang dulunya terbatas menjadi tidak terbatas dikarenakan adanya perkembangan teknologi yang selalu mengalami perubahan. Perkembangan teknologi di zaman ini menuntut semua bidang dalam kehidupan untuk mampu berintegrasi dengan internet, tidak terkecuali dalam bidang pendidikan yang mampu membantu guru dalam memperlancar proses pembelajaran.

Sebagaimana telah dimaklumi bahwa dalam lingkup pendidikan tentunya menuntut adanya pergeseran paradigma dalam proses pembelajaran yang dahuunya pembelajaran konvensional menjadi pembelajaran berbasis digital (Arifin \& Setyawan, 2012). Sehingga pendidikan dapat diartikan sebagai usaha sadar dan terencana untuk mewujudkan suasana belajar dan proses pembelajaran yang membuat siswa menjadi aktif dalam mengembangkan potensi yang dimilikinya (Undang-undang No 23 tahun 2003). Proses pengembangan potensi diri peserta didik dapat dilakukan melalui pembelajaran yang unggul. Menurut Hanafiah dan Suhana (2012), untuk membuat pembelajaran yang unggul diperlukan guru yang profesional sehingga mampu menghasilkan produk yang unggul, untuk mewujudkan hal tersebut diperlukan profesionalisasi secara berkelanjutan sehingga melahirkan para guru yang memiliki profesionalitas dan profesionalisme.

Keprofesionalisme seorang guru dapat dibuktikan dengan kompetensi yang dimilikinya yang dapat menunjang peningkatan kualitas guru sehingga dapat mendorong proses dan kinerja seorang guru. Kompetensi tersebut antara lain: (1) kompetensi pedagogik, (2) kompetensi kepribadian, (3) kompetensi sosial, dan (4) kompetensi profesional. Menurut Karwati dan Priansa (2014), seorang guru dapat dikatakan profesional apabila guru tersebut memiiki kemampuan dalam penguasaan materi pembelajaran secara luas dan mendalam sehingga memungkinkan konten pembelajaran yang terintegrasi dengan teknologi informasi dan komunikasi (TIK). Untuk itu, penting diadakannya pengembangan kompetensi guru. Saat ini, kompetensi guru dalam menghadapi era revolusi industri 4.0 menjadi salah satu substansi yang sedang dibahas DPR RI dalam penyusunan RUU guru.

Peningkatan kompetensi guru dapat dilakukan melalui perbaikan sistem rekrutmen guru. Dimana Pola rekrutmen yang dilakukan tidak hanya menguji kemampuan intelektual para calon guru, tetapi juga menguji kemampuan mental dan kepribadian calon guru dalam menghadapi segala tantangan era Revolusi Industri 4.0. setiap permasalahan dan kendala yang dihadapi oleh guru di daerah akan terakomodasi apabila pola peningkatan kompetensi guru bersifat botton up sehingga nantinya permasalahan tersebut dapat dilakukan pengkajian secara bersama. Berangkat dari hal tersebut maka tentunya guru memiliki peran penting karena guru merupakan aktor dalam upaya organisasi mikro pendidikan, guru harus mampu menjalanakan tugasnya dengan baik sehingga mampu menghasilkan sumber daya manusia (siswa) yang tentunya mempunyai kemampuan hidup di era revolusi industri 4.0.

Dalam menghadapi era revolusi industri 4.0, dibutuhkan profesionalisme seorang guru yang tidak hanya mahir dalam bidang pengetahuan saja namun juga memiliki keterampilan dan kreatifitas, HOTS, literasi serta melek teknologi. Untuk memulainya diperlukan adanya informasi dan pengetahuan tentang bagian dunia yang dapat mengembangkan kesadaran untuk memahami hal-hal yang lebih lebik baik daripada keadaan diri kita sendiri, memahami hubungan dengan masyarakat lain, maupun isuisu yang terjadi dalam era revolusi industri 4.0. Berdasarkan uraian tersebut, tulisan ini akan mengkaji upaya yang dapat dilakukan guru dalam mengembangkan profesionalisme guru untuk menghadapi era revolusi industri 4.0. sehingga nantinya guru mampu mengembangkan profesionalisme untuk menghadapi era revolusi 4.0. 


\section{METODE}

Metode yang digunakan adalah studi kepustakaan, menurut Nazir (2003) mengemuakan bahwa "studi kepustakaan adalah teknik pengumpulan data dengan mengadakan studi penelaahan terhadap buku-buku, literatur- literatur, catatan-catatan, dan laporan-laporan yang ada hubungannya dengan masalah yang dipecahkan." Peneliti melakukan kajian yang berkaitan dengan topik penelitian, mengumpulkan informasi sebanyak-banyaknya dari kepustakaan yang berhubungan.

\section{HASIL DAN PEMBAHASAN}

Era revolusi industri 4.0 telah merambah disegala penjuru yang memiliki care atau penggerak. Uraian Friedman (2006) menunjukkan bahwa gerak perubahan itu selalu dipicu oleh perkembangan teknologi yang melahirkan era revolusi industri 4.0. Pada era ini memunculkan kemajuan disegala bidang yang signifikan dimana semua bidang dalam kehidupan dapat terhubung secara langsung dengan internet sehingga dapat disebut juga dengan era digital. Revolusi industri merupakan perubahan keseluruhan melalui penyatuan digital dan internet. Menurut Herman dkk (2015) menyatakan bahwa industri 4.0 adalah istilah untuk menyebut sekelompok teknologi dan organisasi rantai nilai berupa smart factory, CPS, IoT dan loS. Jadi era revolusi ini dapat menjadi perubahan yang menggabungkan antara teknologi otomatis dengan teknologi cyber, sehingga nantinya teknologi mampu menghubungkan aspek dalam kehidupan diseluruh dunia. Dengan adanya revolusi industri tentunya akan membawa banyak sekali perubahan baik dalam bidang apa saja, tentunya dalam bidang pendidikan. Adanya keterkaitan pendidikan dengan revolusi tentunya menuntut pendidik atau guru untuk ikut serta dalam perkembangan teknologi dan mampu menggunakannya dalam membantu proses pembelajaran.

Sebagai tenaga pendidik, peran guru pasti akan mengalami perubahan. Kompetensi tinggi yang wajib dimiliki guru tentunya bertujuan untuk mencetak peserta didik berkarakter unggul. Kompetensi dapat diartikan sebagai suatu kesatuan yang dapat menggambarkan seluruh aspek terkait menjalankan profesi. Kompetensi dapat dimulai dari sederhana hingga kompleks yang terdiri dari (1) penguasaan KD, (2) praktik KD, dan (3) pengembangan KD. Menurut UU No. 14 tahun 2005 tentang guru dan dosen dijelaskan bahwa kompetensi merupakan seperangkat pengetahuan, keterampilan dan perilaku yang harus dimiliki, dihayati, dan dikuasai oleh guru dalam melaksanakan tugas profesinya. Kompetensi guru sebagaimana yang dimaksud diatas meliputi (1) kepribadian, (2) profesional, (3) pedagogik, dan (4) sosial. Kompetensi tersebut disebut kompetensi keguruan. Berdasarkan uraian diatas, kesimpulannya dari kompetensi yaitu kesatuan dari semua aspek apapun yang harus dipunyai dan dipahami pendidik dalam profesinya. Profesi merupakan pekerjaan yang membutuhkan keahlian, dilakukan oleh seseorang, dan memenuhi mutu tertentu. Profesionalisme yaitu penampilan, sikap dan komitmen saat memenuhi profesi. Menurut Ocmar Hamalik dalam bukunya Proses Belajar Mengajar (2001: 118), dijelaskan bahwa guru profesional memiliki bakat, jasmani dan rohani yang sehat, mengamalkan pancasila dan mempunyai pengetahuan atau pengalaman luas. Filosofi Ki Hajar Dewatara: ing ngarso sung tuladha, ing madya mangun karso, tut wuri handayani harus dimiliki guru di era yang serba maju ini. Pengembangan diri dalam keahlian dan literasi menjadi kunci keprofesionalan seorang guru.

Hal-hal yang dapat dilakukan aspek pendidikan dalam mengimbangi kemajuan yaitu diawali dengan perbaikan rekrutmen guru yang selektif dan memenuhi standar mutu pendidikan. Rekrutmen berisi tentang pengujian pengetahuan, psikologis, dan kepribadian. Untuk itu dibutuhkan suatu cara mengembangkan profesionalisme seorang guru, sehingga guru yang tidak hanya mahir dalam bidang pengetahuan. Upaya yang dapat ditempuh antara lain meningkatkan keterampilan dan kreatifitas 
seorang guru, keterampilan yang dapat dikembangkan dalam menghadapi abad 21 bisa disingkat dengan 4C (communication, collaboration, critical thinking and problem solving, dan creativity), selain itu seorang guru juga harus memiliki keterampilan berpikir tingkat tinggi (HOTS), literasi serta melek teknologi. Jadi, perlu diadakan peningkatan kualitas profesionalisme karena dengan peningkatan kualitas tersebut peserta didik dapat meningkatkan kualitas pendidikan di Indonesia, dan juga karena guru harus menjadi lokomotif pendidikan.

\section{SIMPULAN}

Berdasarkan pemaparan di atas dapat disimpulkan bahwa guru dituntut menjadi profesional dan memiliki kompetensi tinggi untuk menghasilkan peserta didik yang mampu menjawab tantangan Revolusi Industri 4.0. Untuk menjadi guru yang mampu menjawab tantangan era revolusi industri dituntut untuk memiliki beberapa kompetensi keguruan yang dapat ditunjukakkan dalam bentuk unjuk kerja dan dapat dipertanggung jawabkan dalam upaya mencapai suatu tujuan. Kompetensi guru yang dimaksud antara lain kompetensi kepribadian, kompetensi pedagogik, kompetensi profesional dan kompetensi sosial. Sehingga kompetensi dapat disimpulkan sebagai suatu kesatuan yang utuh antara pengetahuan, keterampilan, dan perilaku yang harus dikuasai oleh guru dalam melaksanakan tugas profesinya. Untuk menjadi guru yang profesional yang mampu menghadapi era revolusi 4.0 dibutuhkan suatu keterampilan 4C (communication, collaboration, critical thinking and problem solving, dan creativity), HOTS, literasi, serta melek teknologi.

\section{DAFTAR PUSTAKA}

Arifin, Z dan Setyawan. (2012). Pengembangan Pembelajaran Aktif dengan ICT. Yogyakarta: Skripta Media Creative.

Friedman, T. (2006). Sejarah Ringkas Abad 21. Dian rakyat.

Hamalik, O. (2011). Proses Belajar Mengajar. Jakarta: Bumi Aksara.

Karwati, E dan Priansa. (2014). Management Kelas. Bandung: Alfabeta.

Nazir, Muhammad. (2003). Metode Penelitian. Jakarta: Ghalia Indonesia.

Nurkholis, M.A dan Badawi. (2019). Profesionalisme Guru Diera Revolusi Industri 4.0. Palembang: diakses dari https://jurnal.univpgripalembang.ac.id/index.php/Prosidingpps/article/download/2 $571 / 2383$

Pemerintah Republik Indonesia. (2016). Permendikbud tentang Guru dan Dosen (Permendikbud Nomor 14 tahun 2005). Jakarta: diakses dari http://luk.staff.ugm.ac.id/atur/UU14-2005GuruDosen.pdf.

Pemerintah Republik Indonesia. (2016). Permendikbud tentang Sistem Pendidikan Nasional (Permendikbud Nomor 20 tahun 2003). Jakarta: diakses dari https://kelembagaan.ristekdikti.go.id/wpcontent/uploads/2016/08/UU_no_20_th_2 003.pdf.

Prastowo, A. (2012). Metode Penelitian Kualitatif dalam Perspektif Rancangan Penelitian. Yogyakarta: Ar-Ruzz Media.

Ramayulis. (2005). Metode Pendidikan Agama Islam. Jakarta: Kalam Mulia.

Ramayulis. (2013). Profesi dan Etika Keguruan. Jakarta: Kalam Mulia.

Supriyadi, D. (1999). Mengangkat Citra dan Martabat Guru. Yogyakarta: Adicita Karya Nusa.

Wahyuni, D. (2018). Peningkatan Kompetensi Guru Menuju Era Revolusi Industri 4.0. Vol $X$, No 24. Jakarta: diakses dari https://berkas.dpr.go.id/puslit/files/info_singkat/Info\%20Singkat-X-24-II-P3DIDesember-2018-218.pdf.

Yamin. (2006). Sertifikasi Profesi Keguruan di Indonesia. Jakarta: Gaung Persada Press. 